\title{
ASSESSING THE HYDROLOGIC EFFECTS OF URBANIZATION THROUGH NUMERICAL MODELING USING SWAT: A CASE STUDY OF LAGUNA DE BAY BASIN
}

\author{
J.M. Jamilla ${ }^{1 *}$, J. Serrano ${ }^{1}$, B.C. Hernandez ${ }^{1}$, E. Herrera ${ }^{1,2}$ \\ ${ }^{1}$ National Hydraulic Research Center, University of the Philippines, Diliman, Quezon City, 1101, Philippines - (jmjamilla, \\ jsserrano, bbhernandez) @up.edu.ph \\ ${ }^{2}$ Institute of Civil Engineering, University of the Philippines, Diliman, Quezon City, 1101, Philippines - \\ eugene.herrera@coe.upd.edu.ph
}

KEY WORDS: Land Cover Change, Hydrology, Runoff, ArcSWAT, GIS, Water Balance

\begin{abstract}
:
Laguna de Bay, having a surface area of about $900 \mathrm{~km}^{2}$ is the largest freshwater lake in the Philippines, and is the most important water body in Metro Manila with its variety of uses ranging from aquaculture, irrigation, water supply and flood control. Due to its available resources and strategic location, over extraction, land conversion, and urbanization, have resulted in massive changes in the lake's watershed. The objective of this study is to simulate the impact of land cover change, particularly urbanization, on the hydrology of Laguna de Bay watershed. By hypothetically converting brushland to urban areas and using ArcSWAT to simulate the effects of urbanization, discharges and water balances were assessed. The long-term hydrologic simulations showed an annual increase of $20.6 \mathrm{~m}^{3} / \mathrm{s}(68 \%)$ in surface runoff and a $12.8 \mathrm{~m}^{3} / \mathrm{s}(26 \%)$ decrease in groundwater recharge for the entire watershed as urban areas increase. The mean seasonal flows were $75.2 \mathrm{~m}^{3} / \mathrm{s}$ during the dry season and $149.4 \mathrm{~m}^{3} / \mathrm{s}$ during the wet season for the original land cover, and $70.2 \mathrm{~m}^{3} / \mathrm{s}$ and $154.1 \mathrm{~m}^{3} / \mathrm{s}$ for the urbanized land cover, during the dry and wet seasons, respectively. Water percolating into the aquifers beneath the ground were also lessened by $13.6 \mathrm{~m}^{3} / \mathrm{s}(23 \%)$. The calibration of Marikina subbasin resulted to a satisfactory percent bias (PBIAS), Nash-Sutcliffe (NSE), and the ratio of the root-mean-square error to the standard deviation of measured data (RSR). Other subbasins resulted in a relatively lower performance rating due to limited available monitoring stations within the basin.
\end{abstract}

\section{INTRODUCTION}

Laguna de Bay, also referred to as Laguna Lake, is the largest freshwater lake in the Philippines, and the third largest in Southeast Asia. It serves as a major source of fisheries and aquaculture in the country. It is also a major transportation route between the towns along the shore of the lake. The Bay is also used for power generation, irrigation, industrial cooling, an important source of potable water, and flood detention basin for mitigating Metro Manila waters (Vargas-Nguyen, 2015). Due to its available resources and strategic location, over extraction, land conversion, and urbanization, have resulted in massive changes in the lake's watershed.

For the past decades, there has been major land cover changes in the basin - from $65.11 \%$ of agricultural land in 1988 , it significantly decreased to $29.53 \%$ in 2015 . There is also an annual decrease of $6.56 \%$ of forest cover in the lake's watershed (Valerio 1990). Majority of these conversions are due to rapid industrialization and urbanization. From $4.48 \%$ in 1988, builtup areas increased to $9.90 \%, 17.18 \%$, and $17.77 \%$ in 2004 , 2010 , and 2015, respectively.

According to the Wealth Accounting and the Valuation of Ecosystem Services (2015), in 2014, Biochemical Oxygen Demand (BOD) load in the lake was composed of $2 \%$ forest waste, $3 \%$ solid waste, $5 \%$ agricultural waste, $9 \%$ industrial waste, and $81 \%$ domestic waste. This means that land conversion due to urban sprawl is one of the major causes of water quality deterioration of Laguna Lake.

Hydrologic models can be used to simulate how water moves within a watershed. They are also capable in replicating the impacts of different land cover, soil, and even water conservation structures within a basin. These models are important tools in understanding the hydrological behaviour of watersheds which can be very beneficial, especially for policy makers, in implementing necessary conservation measures and efforts concerning watershed management (Prasad et al., 2020).

The objective of this study is to simulate the impact of land cover change, particularly urbanization, on the hydrology of Laguna de Bay watershed. Expanding impervious surfaces reduces infiltration during storm events which eventually leads to an increase in surface runoff and a decline in aquifer recharge (Zhou et al., 2013). This means that more urbanized areas have higher risk for flooding, water shortage, and water quality deterioration.

\section{DATA AND METHODS}

\subsection{Study Site}

Laguna Lake is the largest lake in the country having a surface area of about $900 \mathrm{~km}^{2}$ and an average depth of 2.5 meters. Laguna de Bay Basin is divided into 24 sub-basins which are bounded by Laguna province in the east, west, and southwest, Rizal in the north and northeast, and Metro Manila in the northwest. The maple-shaped Laguna Lake has a total shoreline length of $285 \mathrm{~km}$ and is sectioned into four (4) segments namely West Bay, Central Bay, East Bay, and South Bay. 


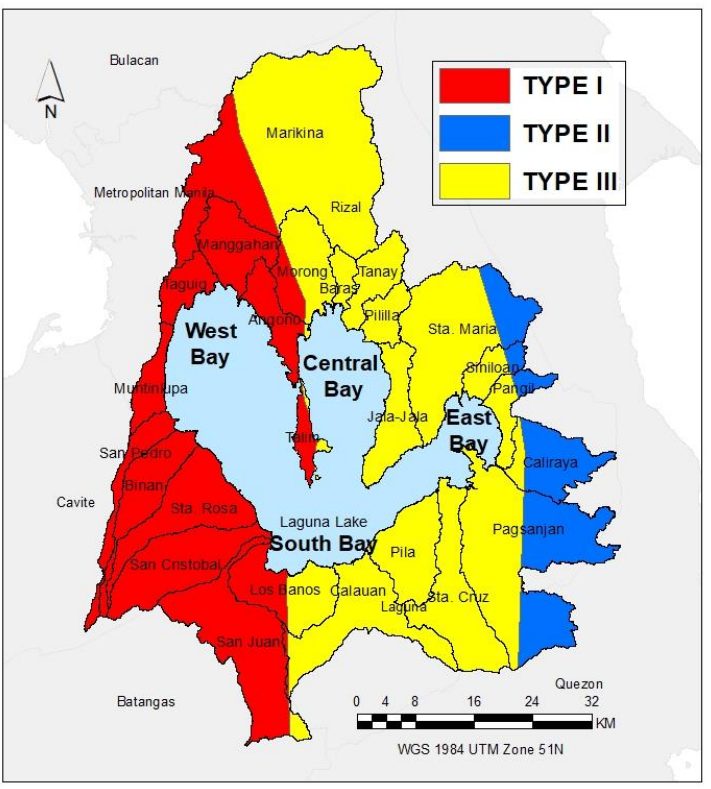

Figure 1. Climate map, subbasins, and relative locations of the bays of Laguna de Bay watershed.

The rainfall distribution within the basin varies at different times of the year. Generally, higher precipitation is experienced at the West Bay where the mountainous parts of the watershed are located. The Central, South, and some parts of the East Bay experience wet and dry seasons. The rest of the East Bay have wet seasons and experience short dry seasons.

\subsection{Data Used}

2.2.1 Digital Elevation Model: DEM from Interferometric Synthetic Aperture Radar (IFSAR) with a spatial resolution of 10 meters was used for the extraction of morphological parameters (e.g., basin boundary, river network, etc) and the basis in performing the watershed delineation.

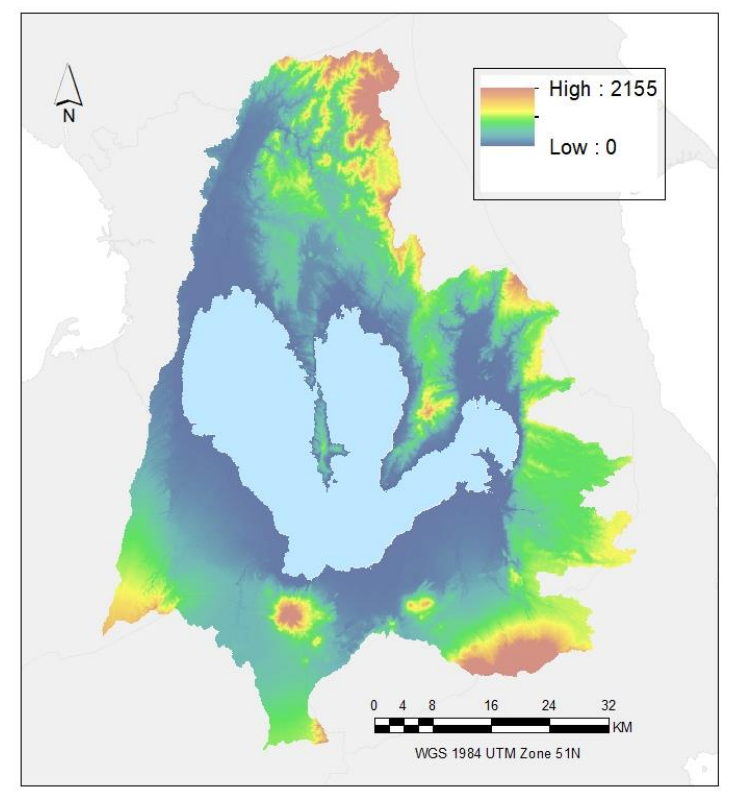

Figure 2. Digital Elevation Model (DEM) of the study area.
2.2.2 Soil: The soil type was obtained from the Food and Agricultural Organization (FAO) database. This database contains soil profile information from various field projects and the soil profile information contained in the volumes that accompanied the Soil Map of the World (FAO-UNESCO, 197181 ). For the study area, the soil types used were classified into seven (7) categories.

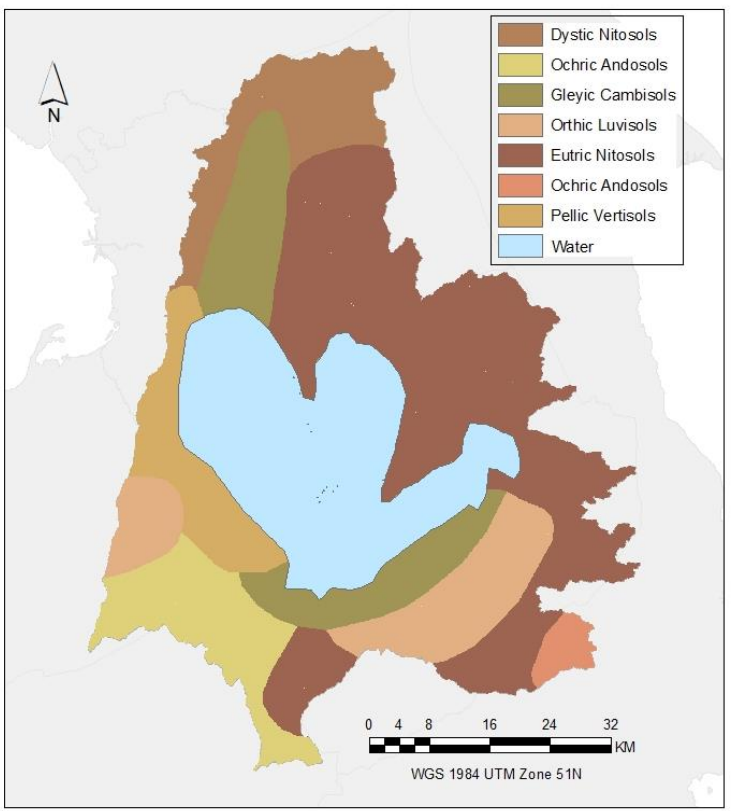

Figure 3. Soil map of the study area.

\begin{tabular}{|c|c|c|}
\hline $\begin{array}{l}\text { FAO Soil } \\
\text { ID }\end{array}$ & Soil Unit & Description \\
\hline Nd66-2-3b & $\begin{array}{l}\text { Dystic } \\
\text { Nitosols }\end{array}$ & $\begin{array}{l}\text { Low-activity clay, } \mathrm{P} \\
\text { Fixation, strongly } \\
\text { structured }\end{array}$ \\
\hline To26-2bc & $\begin{array}{l}\text { Ochric } \\
\text { Andosols }\end{array}$ & $\begin{array}{l}\text { Allophanes or Al-humus } \\
\text { complexes }\end{array}$ \\
\hline $\mathrm{Bg} 8-2-3 \mathrm{a}$ & $\begin{array}{c}\text { Gleyic } \\
\text { Cambisols }\end{array}$ & Moderately developed soils \\
\hline Lo68-2-3b & $\begin{array}{l}\text { Orthic } \\
\text { Luvisols }\end{array}$ & $\begin{array}{l}\text { High base status, high- } \\
\text { activity clay }\end{array}$ \\
\hline $\mathrm{Ne} 65-3 \mathrm{bc}$ & Eutric Nitosols & $\begin{array}{l}\text { Low-activity clay, P } \\
\text { Fixation, strongly } \\
\text { structured }\end{array}$ \\
\hline To27-2-3b & $\begin{array}{l}\text { Ochric } \\
\text { Andosols }\end{array}$ & $\begin{array}{c}\text { Allophanes or Al-humus } \\
\text { complexes }\end{array}$ \\
\hline Vp65-3a & $\begin{array}{c}\text { Pellic } \\
\text { Vertisols }\end{array}$ & $\begin{array}{c}\text { Alternating wet-dry } \\
\text { conditions, rich in swelling } \\
\text { clays }\end{array}$ \\
\hline Water & Water & - \\
\hline
\end{tabular}

Table 1. FAO Soil Classification of the study area.

2.2.3 Land Cover: The 2015 land cover map was obtained from the National Mapping and Resource Mapping Authority (NAMRIA). It was further processed using Geographic Information Systems (GIS) to be ready for input into the SWAT model. Table 2 shows the reclassified land cover categories based on the SWAT land cover classifications. 


\begin{tabular}{cc}
\hline $\begin{array}{c}\text { NAMRIA Land Cover } \\
\text { Classification }\end{array}$ & SWAT Classification \\
\hline Closed/Open Forest & Forest \\
Built-up & Urban \\
Annual/Perennial Crop & Agriculture \\
Grassland & Range-Grasses \\
Brush/Shrubs & Range-Brushes \\
Inland Water/Fishpond & Water \\
Mangrove Forest & Wetland-Forested \\
Marshland/Swamp & Wetland-Non-forested \\
Open/Barren & Barren \\
\hline
\end{tabular}

Table 2. Reclassification of land cover classes for SWAT Modelling.

Land cover plays a significant role in the hydrology of watersheds as it characterizes the topography of the area being modelled.

2.2.4 Meteorological Data: Spatially distributed local weather gauges covering the simulation period of 1995 to 2019 were obtained from the Philippine Atmospheric, Geophysical and Astronomical Administration (PAGASA). Supplementary rainfall and other weather parameters such as temperature, relative humidity, wind speed, and solar radiation were also acquired from the Department of Science and Technology Advanced Science and Technology (DOST-ASTI), Effective Flood Control Operation System (EFCOS), and International Rice Research Institute (IRRI).

2.2.5 Discharge Data for Calibration and Validation: Observed river flows or discharges are important components in hydrologic models. These discharges can be used to calibrate and validate simulations to assure that the watershed parameters set are representative of their in-situ data.

Department of Public Works and Highways (DPWH) discharge data and ASTI water level data were utilized for the calibration and validation of the SWAT models used in this study.

\subsection{Methodology}

The methodology of this study consists of four main steps: (1) SWAT input preparation, (2) SWAT simulation, (3) calibration and validation, and (4) output visualization

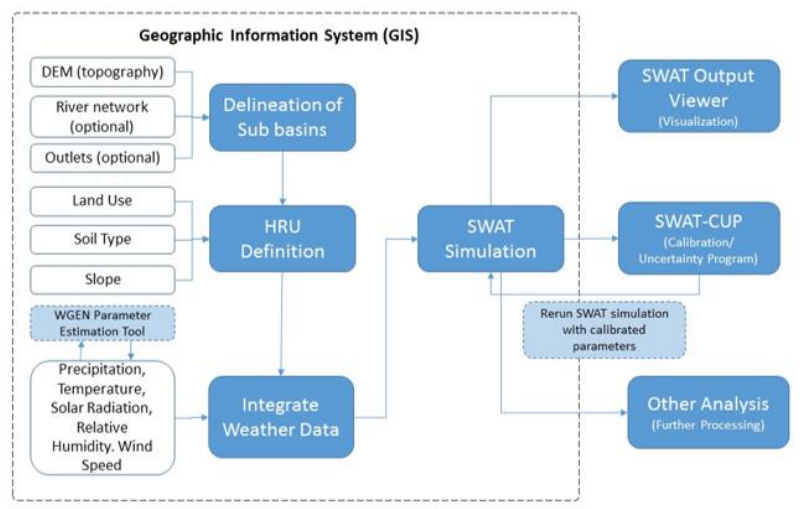

Figure 4. General workflow of the study.
2.3.1 SWAT Input Data: DEM and soil data were further pre-processed in GIS to be ready for input into the SWAT model.

For this study, the reclassified SWAT-ready 2015 land cover was further recategorized. Brushland, which was $19 \%$ of the 2015 land cover of Laguna de Bay basin, was chosen among all the vegetation to be converted to built-up because first, it is susceptible to urbanization due to its landscape, and second, its area covered was not as small as the grassland (4\%) and not as big as the agricultural land $(30 \%)$. This hypothetical land conversion was done to simulate the impact of land cover change, particularly, urbanization, on the hydrological processes involved in Laguna de Bay Basin using SWAT models.

For the meteorological data, all available local weather stations within and near the basin were utilized to ensure that the hydrological models would accurately predict streamflow and any other water movement within the basin.

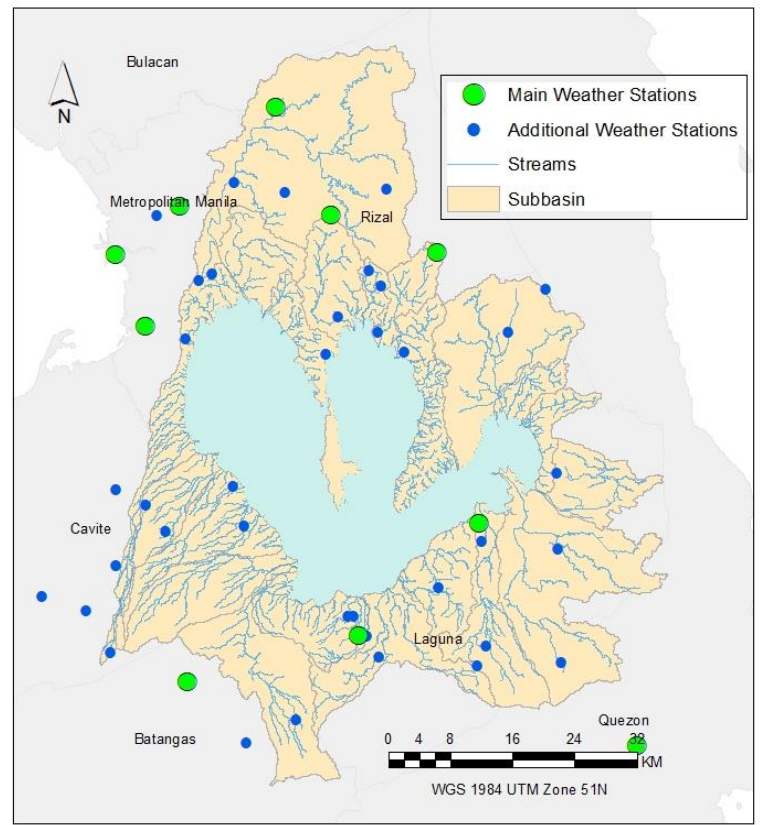

Figure 5. Weather stations used in the SWAT models.

Ten local monitoring stations (green circles) with a period of 1995 to 2019 were processed using Weather Generator (WGN) for the SWAT Database. These continuous long-term datasets served as the main stations and were used to generate values for the missing data from the additional weather stations (blue circles) with monitoring periods ranging from 2011 to 2019.

2.3.2 SWAT Simulation, Calibration, and Visualization: The Soil and Water Assessment Tool (SWAT) is a watershed scale, continuous, and long-term distributed model which is designed to quantify the rainfall-runoff relationship considering the natural heterogeneity of the watershed and the spatial distribution of topography, vegetation, land cover, soil characteristics, and climate. The GIS integration into the SWAT model enables the spatial visualization of the hydrologic inputs, including topography, land cover, and soil type.

For this study, two (2) hydrological models were examined: (1) using the original 2015 land cover and (2) urbanized 2015 land cover. Both models were processed using ArcSWAT and used 
the same inputs for the rest of the parameters such as DEM, soil, and weather data with simulation period of 1995-2019.

2.3.3 Calibration, Validation, and Visualization: After generating the SWAT models for the original land cover, these simulations were calibrated and validated using SWAT-CUP. SWAT-CUP is a computer program used for sensitivity analysis, calibration, validation, and uncertainty analysis of a SWAT model.

Sensitivity analysis was performed for each subbasin. This is a crucial part of the model development as it involves analytical evaluation of input parameters needed in model validation (Khalid et.al., 2016). Parameters with $p$-value of less than 0.05 were selected for each subbasin. A variable with a low $p$-value (less than 0.05) indicates that changes in the said variable's value are related to the changes in the response variable. This means that there is only a $5 \%$ chance that the results would occur in a random distribution. Thus, there is a $95 \%$ probability of being correct that the parameters chosen would have some effect on the results. For this simulation, GW_REVAP, REVAPMN, GWQMN, CN2, SOL_AWC, SLSUBBSN, OV_N, ESCO, and HRU_SLP were among the sensitive parameters used in the calibration and validation.

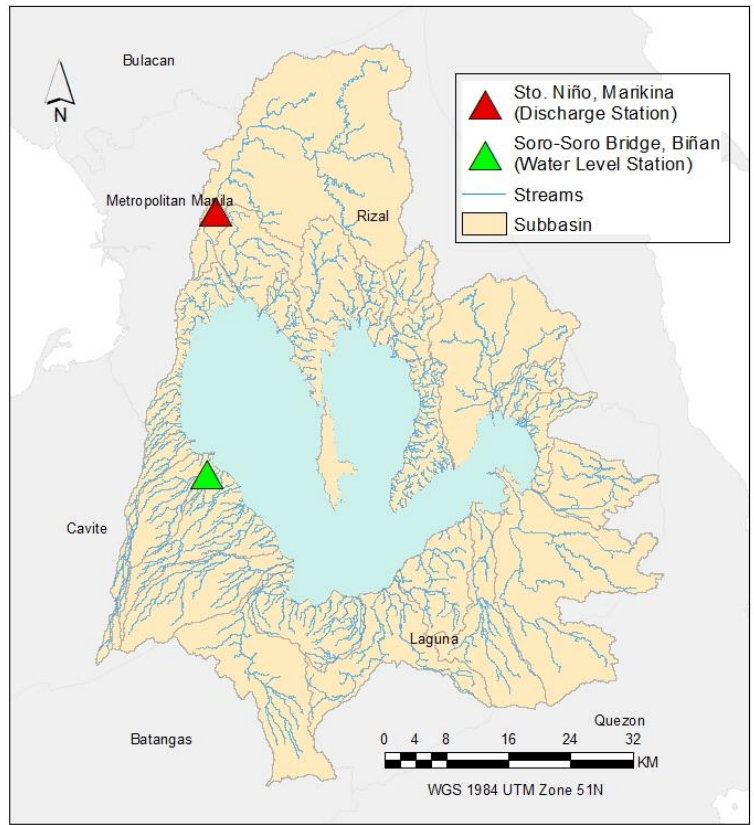

Figure 6. Discharge stations used in the SWAT models.

Due to limited daily discharge data available, three (3) methods were used to generate discharge data needed in calibrating and validating the models: (1) for Marikina subbasin, observed daily discharges from Sto. Niño, monitoring station were used, (2) for Biñan subbasin, a rating curve was generated to convert observed water level data from Soro-Soro Bridge to daily discharge data using a hydraulic model, and (3) Area-discharge ratio calculations which equates the ratio of the streamflow of two (2) stream locations to the ratio of their respective drainage areas, were performed to estimate the flows for the remaining 22 subbasins.

The calibrated parameters from the original land cover models were integrated to the urban land cover models using python scripts before running them again in SWAT Output Viewer, where the calibrated flows and water balances were extracted.

\section{RESULTS}

\subsection{Land Cover Change}

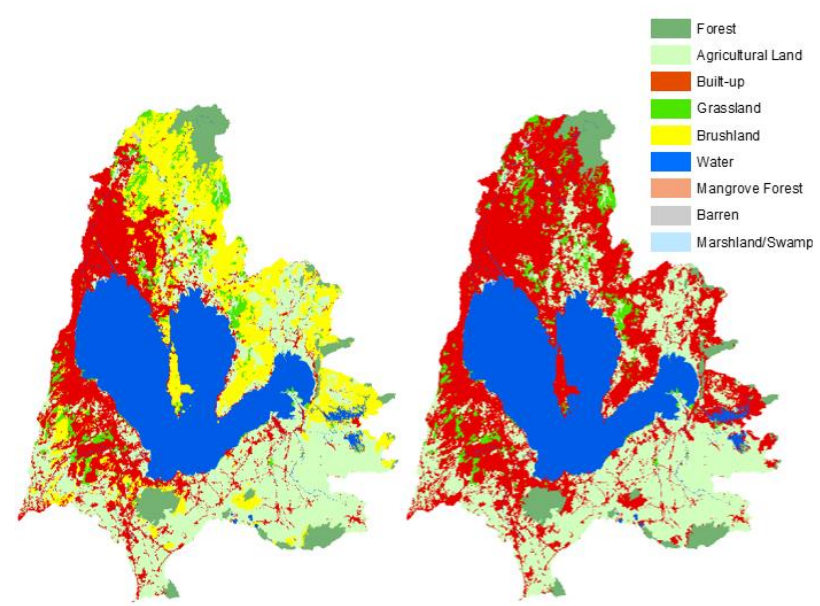

Figure 7. Original (left) and urbanized (right) 2015 land covers.

In 2015, the land cover of Laguna de Bay Basin was composed of $18 \%$ built-up and $19 \%$ brushland. By hypothetically converting brushland to urban areas, the new land cover classification resulted in $37 \%$ built-up. Table 3 shows the area and percentages for each land cover classification.

\begin{tabular}{ccccc}
\hline Land Cover & \multicolumn{2}{c}{ Original } & \multicolumn{2}{c}{ Urbanized } \\
Classification & Area $\left(\mathrm{km}^{2}\right)$ & $\%$ & Area $\left(\mathrm{km}^{2}\right)$ & $\%$ \\
\hline Forest & 201 & 5 & 201 & 5 \\
Agricultural Land & 1131 & 30 & 1131 & 30 \\
Built-up & 680 & 18 & 1404 & 37 \\
Grassland & 147 & 4 & 147 & 4 \\
Brushland & 725 & 19 & - & - \\
Water & 932 & 24 & 932 & 24 \\
Barren & 8 & 0.2 & 8 & 0.2 \\
Non-Forested & 2 & 0.1 & 2 & 0.1 \\
Wetland & &
\end{tabular}

Table 3. Land Cover Change Classification.

Tanay subbasin yielded the largest percentage of converted brushland to built-up areas resulting in $78 \%$ of its area as urban, followed by JalaJala and Sta. Maria with $72 \%$ and $54 \%$ of paved surfaces, respectively.

\subsection{River Discharges}

Continuous land cover change can have major impact on the peak discharges and water balance within the watershed. Table 4 shows the annual average discharges for the whole Laguna de Bay Basin. 


\begin{tabular}{|c|c|c|c|}
\hline Year & $\begin{array}{l}\text { Discharges } \\
\text { using the } \\
\text { original } \\
\text { land cover } \\
\left(\mathrm{m}^{3} / \mathrm{s}\right)\end{array}$ & $\begin{array}{l}\text { Discharges } \\
\text { using the } \\
\text { urbanized } \\
\text { land cover } \\
\left(\mathrm{m}^{3} / \mathrm{s}\right)\end{array}$ & $\begin{array}{c}\Delta \text { in Peak } \\
\text { flows }\end{array}$ \\
\hline 1995 & 622.40 & 794.62 & $28 \%$ \\
\hline 1996 & 741.15 & 787.33 & $6 \%$ \\
\hline 1997 & 614.55 & 739.96 & $20 \%$ \\
\hline 1998 & 775.77 & 954.86 & $23 \%$ \\
\hline 1999 & 728.76 & 788.72 & $8 \%$ \\
\hline 2000 & 639.17 & 792.85 & $24 \%$ \\
\hline 2001 & 668.07 & 667.76 & $0 \%$ \\
\hline 2002 & 451.68 & 548.60 & $21 \%$ \\
\hline 2003 & 1055.03 & 1119.52 & $6 \%$ \\
\hline 2004 & 595.08 & 927.77 & $56 \%$ \\
\hline 2005 & 524.00 & 679.98 & $30 \%$ \\
\hline 2006 & 511.70 & 515.60 & $1 \%$ \\
\hline 2007 & 836.09 & 815.83 & $-2 \%$ \\
\hline 2008 & 626.00 & 616.10 & $-2 \%$ \\
\hline 2009 & 1013.45 & 1170.60 & $16 \%$ \\
\hline 2010 & 505.11 & 648.82 & $28 \%$ \\
\hline 2011 & 805.42 & 1033.57 & $28 \%$ \\
\hline 2012 & 1903.38 & 1945.01 & $2 \%$ \\
\hline 2013 & 1416.92 & 1657.55 & $17 \%$ \\
\hline 2014 & 975.54 & 1253.68 & $29 \%$ \\
\hline 2015 & 960.97 & 1217.75 & $27 \%$ \\
\hline 2016 & 612.36 & 812.36 & $33 \%$ \\
\hline 2017 & 1488.65 & 1702.71 & $14 \%$ \\
\hline 2018 & 788.07 & 1026.63 & $30 \%$ \\
\hline 2019 & 764.53 & 864.51 & $13 \%$ \\
\hline
\end{tabular}

Table 4. Annual Average Peak Discharges for Laguna de Bay Basin.

Table 4 shows that urbanization increased the peak discharges around $138 \mathrm{~m}^{3} / \mathrm{s}$ (18\% increase) annually. The mean seasonal flows were $75.2 \mathrm{~m}^{3} / \mathrm{s}$ during the dry season and $149.4 \mathrm{~m}^{3} / \mathrm{s}$ during the wet season for the original land cover, and $70.2 \mathrm{~m}^{3} / \mathrm{s}$ and $154.1 \mathrm{~m}^{3} / \mathrm{s}$ for the urbanized land cover, during dry and wet season, respectively.

The long-term hydrologic simulations as seen in Figure 8 show that the annual average peak discharges for Tanay subbasin increased with the increase of the urban land cover. On the hand, Pagsanjan, which was composed of $78 \%$ agricultural land and only $12 \%$ urban area, showed minimal increase in peak discharges. Watershed with a significant amount of vegetation would result in slower movement of water into the river channels, increasing the lag time, as vegetation intercepts precipitation. Water is also lost due to transpiration and evaporation, which also reduces the peak discharges of a river.

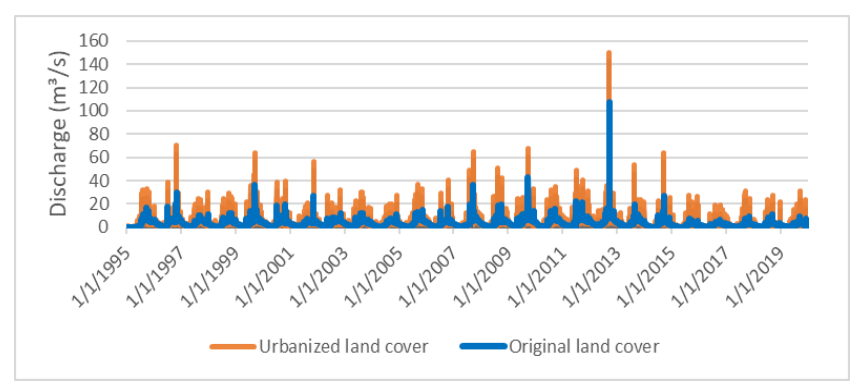

(a)

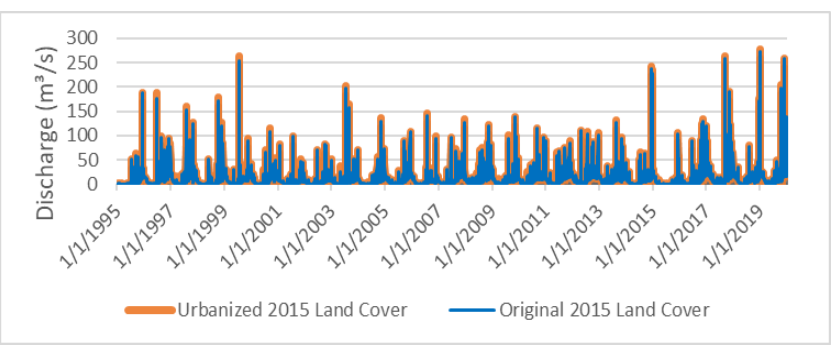

(b)

Figure 8. Simulated annual mean peak discharges for (a) Tanay subbasin and (b) Pagsanjan subbasin.

\subsection{Water Balance}

As impervious surfaces continue to expand, the lesser the storage capacity for water in urban areas become. With this, urban streams would overflow more quickly, have higher peak discharges, with higher flow velocities which would increase the risk of flooding during storm events. Table 5 shows the comparison between the surface runoff and groundwater recharge using the two (2) land covers.

\begin{tabular}{ccccc}
\hline \multirow{2}{*}{ Year } & \multicolumn{2}{c}{ Original land cover } & \multicolumn{2}{c}{ Urbanized land cover } \\
\cline { 2 - 5 } & $\begin{array}{c}\text { Surface } \\
\text { runoff } \\
(\mathrm{mm})\end{array}$ & $\begin{array}{c}\text { Groundwater } \\
\text { recharge } \\
(\mathrm{mm})\end{array}$ & $\begin{array}{c}\text { Surface } \\
\text { runoff } \\
(\mathrm{mm})\end{array}$ & $\begin{array}{c}\text { Groundwater } \\
\text { recharge } \\
(\mathrm{mm})\end{array}$ \\
\hline 1995 & 0.89 & 1.2 & 1.58 & 0.86 \\
1996 & 0.99 & 1.73 & 1.64 & 1.3 \\
1997 & 0.94 & 1.67 & 1.6 & 1.23 \\
1998 & 1 & 1.17 & 1.64 & 0.82 \\
1999 & 1.01 & 1.93 & 1.67 & 1.47 \\
2000 & 1.08 & 1.82 & 1.89 & 1.34 \\
2001 & 0.71 & 1.27 & 1.28 & 0.91 \\
2002 & 0.74 & 1.32 & 1.31 & 0.95 \\
2003 & 1.01 & 1.5 & 1.67 & 1.09 \\
2004 & 0.77 & 1.29 & 1.37 & 0.93 \\
2005 & 0.99 & 1.84 & 1.75 & 1.38 \\
2006 & 0.82 & 1.62 & 1.42 & 1.21 \\
2007 & 0.97 & 1.64 & 1.66 & 1.21 \\
2008 & 0.99 & 1.56 & 1.62 & 1.14 \\
2009 & 1.01 & 1.7 & 1.79 & 1.22 \\
2010 & 1 & 1.83 & 1.68 & 1.38 \\
\hline
\end{tabular}

Table 5. Annual Average Surface Runoff and Groundwater Recharge for Laguna de Bay Basin. 


\begin{tabular}{ccccc}
\hline \multirow{2}{*}{ Year } & \multicolumn{2}{c}{ Original land cover } & \multicolumn{2}{c}{ Urbanized land cover } \\
\cline { 2 - 5 } & $\begin{array}{c}\text { Surface } \\
\text { runoff } \\
(\mathrm{mm})\end{array}$ & $\begin{array}{c}\text { Groundwater } \\
\text { recharge } \\
(\mathrm{mm})\end{array}$ & $\begin{array}{c}\text { Surface } \\
\text { runoff } \\
(\mathrm{mm})\end{array}$ & $\begin{array}{c}\text { Groundwater } \\
\text { recharge } \\
(\mathrm{mm})\end{array}$ \\
\hline 2011 & 1.12 & 1.97 & 1.93 & 1.47 \\
2012 & 1.56 & 2.24 & 2.47 & 1.66 \\
2013 & 1.28 & 2.09 & 2.02 & 1.62 \\
2014 & 0.82 & 1.17 & 1.38 & 0.85 \\
2015 & 0.9 & 1.18 & 1.5 & 0.85 \\
2016 & 0.73 & 1.28 & 1.28 & 0.96 \\
2017 & 1.12 & 1.49 & 1.59 & 1.18 \\
2018 & 0.89 & 1.3 & 1.41 & 1.01 \\
2019 & 0.74 & 1.2 & 1.13 & 0.95 \\
\hline
\end{tabular}

Table 5 (continued). Annual Average Surface Runoff and Groundwater Recharge for Laguna de Bay Basin.

On the average, an annual increase of $20.6 \mathrm{~m}^{3} / \mathrm{s}(68 \%)$ in surface runoff and a $12.8 \mathrm{~m}^{3} / \mathrm{s}(26 \%)$ decrease in groundwater recharge for the entire watershed were observed as urban areas increase. Water percolating into the aquifers beneath the ground were also lessened by $13.6 \mathrm{~m}^{3} / \mathrm{s}(23 \%)$.

The annual average surface runoff when the original land cover was simulated was $14.3 \mathrm{~m}^{3} / \mathrm{s}$ for the dry season and $46.8 \mathrm{~m}^{3} / \mathrm{s}$ for the wet season. For the urban land cover, the runoff for the dry and wet seasons increased by $55 \%$ and $71 \%$, respectively, resulting in $22.1 \mathrm{~m}^{3} / \mathrm{s}$ and $80 \mathrm{~m}^{3} / \mathrm{s}$ surface runoff increase. Consequently, groundwater recharge was reduced for the urban land cover by $22 \%\left(10 \mathrm{~m}^{3} / \mathrm{s}\right)$ during the dry season and $29 \%$ $\left(15.4 \mathrm{~m}^{3} / \mathrm{s}\right)$ during the wet season.

\begin{tabular}{lcccc}
\hline $\begin{array}{l}\text { Land } \\
\text { Cover }\end{array}$ & $\begin{array}{l}\text { Surface } \\
\text { runoff }\end{array}$ & $\begin{array}{l}\text { Groundwater } \\
\text { Recharge }\end{array}$ & $\begin{array}{l}\text { Perco- } \\
\text { lation }\end{array}$ & $\begin{array}{l}\text { Evapo- } \\
\text { transpiration }\end{array}$ \\
\hline Original & $15 \%$ & $24 \%$ & $28 \%$ & $33 \%$ \\
Urbanized & $26 \%$ & $18 \%$ & $22 \%$ & $34 \%$ \\
\hline
\end{tabular}

Table 6. Water Balance of Laguna de Bay Basin.

These differences in values can be due to the expansion of urban areas within the basin. However, this cannot only be associated with land cover change. Differences in topography, geology, human activities, and rainfall variability are also factors that need to be considered.

\subsection{Calibration and Validation}

The accuracy of the models was also tested through calibration and validation. This was done to compare the simulation results such as flows with the actual discharges.

\begin{tabular}{cccccccc}
\hline \multirow{2}{*}{ Subbasin } & \multicolumn{3}{c}{ Calibration } & \multicolumn{3}{c}{ Validation } \\
\cline { 2 - 7 } & NSE & PBIAS & RSR & NSE & PBIAS & RSR \\
\hline Marikina & 0.57 & 17 & 0.65 & 0.46 & 35.1 & 0.74 \\
Biñan & 0.41 & 49.4 & 0.77 & 0.2 & 68.8 & 0.9 \\
\hline
\end{tabular}

Table 7. Calibration and Validation Results.

\begin{tabular}{ccccccc}
\hline \multirow{2}{*}{ Subbasin } & \multicolumn{3}{c}{ Calibration } & \multicolumn{3}{c}{ Validation } \\
\cline { 2 - 7 } & NSE & PBIAS & RSR & NSE & PBIAS & RSR \\
\hline Sta. & 0.32 & 11.5 & 0.83 & -0.17 & 29.9 & 1.08 \\
Maria & & & & & \\
San Juan & 0.35 & 52.5 & 0.81 & -0.22 & 9.2 & 1.11 \\
Pagsanjan & 0.35 & 21.8 & 0.81 & -0.3 & 62 & 1.14 \\
\hline
\end{tabular}

Table 7 (continued). Calibration and Validation Results.

Calibration and validation of the models were done using the observed daily discharges from Sto. Niño monitoring station for Marikina subbasin. Converted daily discharge data from the observed water level data from Soro-Soro Bridge was used for Biñan subbasin. Area-discharge ratio calculations were done to estimate the flows for Sta. Maria subbasin using Sto. Niño monitoring station and converted discharge data from Soro-Soro Bridge for San Juan and Sta. Cruz subbasins. Figure 9 shows the graphs of the simulation results and the their corresponding observed data.

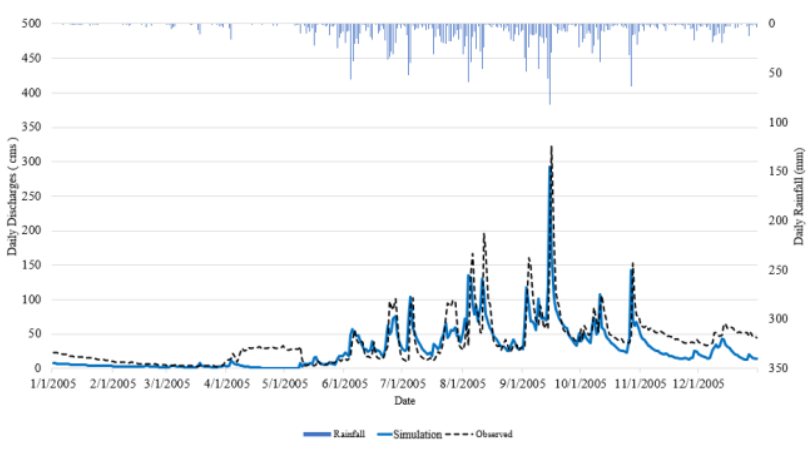

(a)

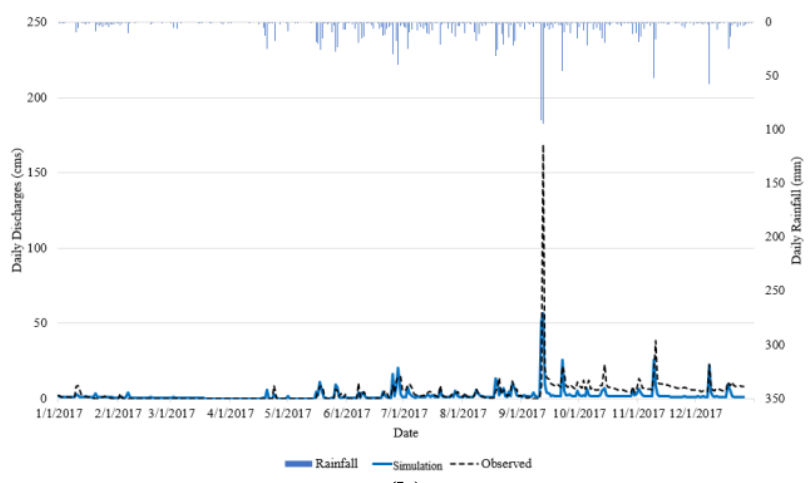

(b)

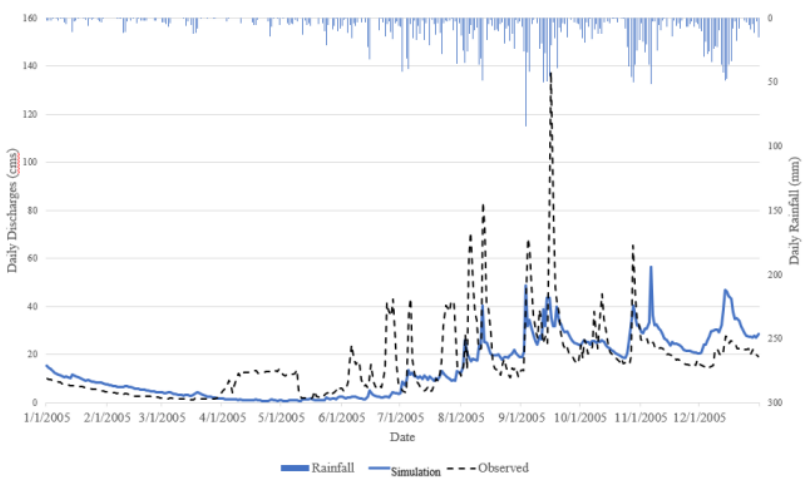

(c)

Figure 9. Calibration plots for (a) Marikina subbasin, (b) Biñan subbasin, and (c) Sta. Maria subbasin. 
The calibration of Marikina subbasin resulted in a satisfactory percent bias (PBIAS), Nash-Sutcliffe (NSE), and the ratio of the root-mean-square error to the standard deviation of measured data (RSR), while Sta. Maria yielded a good performance rating for PBIAS only. Other subbasins resulted in a relatively lower performance rating due to limited available monitoring stations within the basin.

\section{CONCLUSION AND RECOMMENDATIONS}

Hydrologic models were setup using the DEM, soil, land cover, and meteorological data, which were all pre-processed in GIS. These were used as inputs in ArcSWAT to simulate the effects of urbanization within the Laguna de Bay watershed. Results showed that developed lands tend to have higher surface runoff during the wet season and lesser aquifer recharge during the dry season, which leads to a short lag time and an increase in peak discharges.

Urban development has adverse effects on the quality and quantity of groundwater and surface water features. Common consequences are increased peak discharges and frequency of flooding. In addition, as groundwater infiltration reduces, precipitation that previously filled aquifers is instead transported to surface water bodies, altering the flow pattern, causing erosion, among other things. Infiltrating rainwater also acts as a major mechanism for the quality of both ground and surface water. More vegetation means more filters to contaminants in stormwater penetrating the ground.

Urbanization, which generally increases overall runoff, can lead to reducing this filtering mechanism, resulting in higher contaminant loads to water bodies. Furthermore, decrease in the recharge of groundwater can cause water supply shortage during the dry season.

The population density in Laguna de Bay Basin continues to increase hence, the need to urban expansion is inevitable, particularly in the northwest, western, and southern portions of the basin. Rampant land conversions to residential uses and constructions of new settlements close to the shoreline can be very problematic, especially during the wet season, where flooding would presumably occur.

This continuous urban expansion also results in sedimentation of the lake by impeding the flow of turbid waters. In addition, the backflow of Pasig River, which is the sole drainage outlet of Laguna Lake, bring in solid wastes, dissolved pollutants, and saline water during the dry season. On the contrary, this saltwater intrusion is beneficial to the lake's fishermen because of its effect on turbidity, which is a suitable environment for milkfish aquaculture.

Uncontrolled and unplanned land conversions continue to threaten the entire ecosystem of the entire Laguna de Bay watershed. With these, proper sewage and waste management, zoning, monitoring of the lake and its tributaries, and other rehabilitation efforts should be implemented to maintain the long-term viability of the lake not only as an economic area but also, as a water storage reservoir.

\section{ACKNOWLEDGEMENT}

This research study is made possible through the funding support of the Department of Science and Technology -
Philippine Council for Industry, Energy, and Emerging Technology Research and Development (DOST-PCIEERD).

\section{REFERENCES}

Abbaspour, K. C., (n.d.): SWAT Calibration and Uncertainty Programs. Retrieved 2021

Corona, José A.I., Tarendra Lakhankar, Soni Pradhanang, and Reza Khanbilvardi. 2014. "Remote Sensing and Ground-Based Weather Forcing Data Analysis for Streamflow Simulation" Hydrology 1, no. 1 1: 89-111. https://doi.org/10.3390/hydrology 1010089

Ecosystem Accounts Inform Policies for Better Resource Management of Laguna de Bay. Wealth Accounting and Valuation of Ecosystem Services. (2015). Retrieved from www.wavespartnership.org

Edivaldo, A.O., Silva M.T., Ferreira, T.R., Paiva, A. T. C., Assis dos Santos, C., Meiguins de Lima, A. M., de Paulo Rodrigues da Silva, V., de Assis Saviano de Sousa, F., Cadoso Gomes, D. J., 2021: Impacts of land use and land cover changes on hydrological processes and sediment yield determined using the SWAT model, International Journal of Sediment Research. doi.org/10.1016/j.ijsrc.2021.04.002

FAO Corporate Document Repository Working Paper (Part I. Philippines, Seasonal Fishkill Problem in Laguna de Bay) 24: $62 \mathrm{pp}$.

Khalid, K., Ali, M. F., Rahman, N. F., Mispan, M. R., Haron, S., H., Othman, Z., Bachok, M. F., 2016: Sensitivity Analysis in Watershed Model Using SUFI-2 Algorithm. doi.org/10.1016/j.proeng.2016.11.086

Konrad C. P., 2016: Effects of Urban Development on Floods. U.S. GEOLOGICAL SURVEY. Retrieved from https://pubs.usgs.gov/fs/fs07603/.

Li, C., Liu, M., Hu. Y., Shi, T., Qu, X., Walter, M. T., 2018: Effects of urbanization on direct runoff characteristics in urban functional zones. doi.org/10.1016/j.scitotenv.2018.06.211

Prasad, V., Yousef A., Sharma, Navmeet., (2020). Hydrological modeling for watershed management. Journal of Natural Resource Conservation and Management. Vol. 1. 29-34. 10.51396/ANRCM.1.1.2020.29-34.

Urban Water Balance. Sustainable Technologies. (n.d.). Retrieved October 12, 2021

Vargas-Nguyen, V., 2015: Laguna de Bay, Philippines: Environmental Literacy

Zhang, H., Wang, B., Liu, D. L., Zhang, M., Leslie, L. M., Yu, Q., 2020: Using an improved SWAT model to simulate hydrological responses to land use change: A case study of a catchment in tropical Australia. doi.org/10.1016/j.jhydrol.2020.124822

Zhou, F., Xu, Y., Chen, Y., Xu, C.Y., Gao, Y., Du, J., 2013: Hydrological response to urbanization at different spatiotemporal scales simulated by coupling of CLUE-S and the SWAT model in the Yangtze River Delta. doi.org/10.1016/j.jhydrol.2012.12.040 